\title{
CREATING THE MODEL FOR THE IMPLEMENTATION OF MARKETING ATTRIBUTES WHICH DETERMINE DOMESTIC ENTERPRISES COMPETITIVENESS
}

\author{
UDC: 005(497.11) \\ 339.13(497.11) \\ Original Scientific Paper \\ Snežana BEŠIĆ ${ }^{1}$, Cariša BEŠIĆ ${ }^{2}$ \\ ${ }^{1}$ High railway school of professional studies, 11000 Beograd, Zdravka Čelara 14, Republic of Serbia \\ E-mail: snezana.besic@ vzs.edu.rs \\ ${ }^{2}$ University of Kragujevac, Faculty of technical science in Čačak, 32000 Čačak, Svetog Save 65, Republic of \\ Serbia
}

Paper received: 04.09.2018.; Paper accepted: 09.10.2018.

\begin{abstract}
Global market and establishing new competitive relations require a new approach to business organization management, both in the conceptional and organizational sense. Modern organizations that are actively and continually applying modern management methods and techniques have significantly better chances to strenghten their competitive ability on the global market and to take a stable market position with the perspective for further market growth. Therefore, it is necessary for domestic enterprises to implement those management techniques which emphasize long-lasting orientation towards competitiveness - relationship marketing, business quality standardization, as well as other management techniques based on knowledge. Implementation of modern management techniques is an essential precondition for a successful business performance of domestic enterprises. Misunderstanding of marketing is typical for transition economies. Domestic business organizations have to use foreign business experiences in the process of business internationalization, which means that they have to apply actively the concept of integrated marketing. This paper provides an overview of reserch results regarding the managers' attitudes of domestic companies about the need of improving the marketing practice. Also, the overview of the model for applying the marketing attributes which determine the competitiveness of domestic companies has been provided.
\end{abstract}

Keywords: Marketing, Competitiveness, Global market, Management, Knowledge, Model.

\section{INTRODUCTION}

Modern business conditions, characterized by the process of business globalization and changed competitive relations, require the change of existing postulates of managing business organizations, especially from the business practice point of view. According to Kotler and Caslione (2009), globalization and technology are the two main forces that had an influence on creating the new level of intertwined fragility in the world economy. Globalization for manufacturers in a certain country means that they import resources from other countries more often, but they also export their final products more. Technology, in the sense of computers, the Internet and mobile phones, allows streaming of information around the world at incredible speed.

Business organization cannot operate successfully unless it applies modern management methods and techniques. Global business, which starts resembling business in conditions of market turbulence, requires making business decisions related to the real adaptation to the current market situation.

Business organizations that want to keep competitive ability in the long run ought to pay more attention to changes in the environment. According to Kotler and Caslione (2009), the fact is that we are entering the new era of turbulence. 
Turbulence is a new normality. Stability is disappearing and the possibility of predicting events is decreased, so the society is exposed to the action of forces that caused the turbulence. Business turbulence assumes unpredictable and fast changes in internal or external environment of business organizations which affect their organizational structure, (Martinović, 2009).

The most important consequence of the market globalization is the global competition. Competition in the international context existed even before the establishment of the globalization process, but it was not noticeable nor strong. However, global competition is becoming more and more intense. It is considered that as the competitive forces are stronger, it is getting more difficult for industry members to earn attractive profits. The competition in the majority of industries have become internationalized and the enterprises appear on the market through global strategies, (Bešić, \& Đorđević, 2017; Bešić, Đorđević, \& Bešić, 2017).

In order for a modern business organization to achieve competitive ability, it is necessary to own competitive advantage in the form of lower costs of business and product differentiation. According to Porter (2007), creating unique and sustainable competitive position requires:

- Focusing on costs - the organization is trying to achieve cost advantage in the chosen segment,

- Focusing on differentiation - the organization is trying to achieve differentiation in the chosen segment.

Leadership in costs means that the products and services which are being produced and created are of acceptable quality with business costs that are always lower than the ones of competitors, while differentiation means that the manufacturer tends to make his product different from the product or service of competitors. Constant improvement of business productivity allows the reduction of costs, while long-term work on improving business quality allows business organization to place products of standard quality and acceptable price on the global market. Apart from the long-term work on securing quality, continuous innovation is also necessary. The key task in the modern organization management is to perceive the changes in business environment adequately and comprehensively, as well as to formulate the ways in which the enterprise would adapt to the perceived changes. The enterprise can achieve competitive advantage if those ways of overcoming the environmental changes are more effective and more efficient than the ones of the competition. It is considered (Thompson, Sticland, \& Gamble, 2008) that the main characteristics of the future organization are: lower barriers between vertical levels, functions, business units; ability to change and learn fast; cooperative effort among people in different positions.

Domestic enterprises are not competitive on the global market because of the fact that they are not productive enough, which results in higher selling prices and inadequate product quality. The issue of the domestic economy's uncompetitiveness in the international framework has been evident since the late $80 \mathrm{~s}$, but it became specifically noticeable with the beginning of transition in 2001. Negative effects of the world economic crisis have had even bigger influence on the decrease in domestic economy's competitiveness. Global competitiveness indicators, published by the World Economic Forum, point out the fact that the domestic economy is facing the issue of uncompetitiveness for over a decade - the economy of the Republic of Serbia is lagging behind in the terms of competitiveness in comparison with all the Western Balkan countries, except $\mathrm{BiH}$, as well as with all the countries from southestern Europe. During 2017, Serbia improved its global competitiveness position $\left(78^{\text {th }}\right.$ place in the world), but the biggest issue of domestic economy is still a really low level of innovation (95 ${ }^{\text {th }}$ place) (Đorđević, Ćoćkalo, \& Bogetić, 2018). New business conditions require from enterprises to change their ways of doing business, meaning that the outdated business models have to be replaced with new management models based on knowledge.

According to Drucker (2003), modern society is the society of knowledge, as knowledge became the main resource and useful good. In the modern society knowledge is becoming a strategic source of power and wealth and the main social group are the users of that knowledge - people capable of putting it into function of doing business activities. They are creating ideas, information and concepts. For every knowledge worker it is very important to focus on contribution. By applying new knowledge in their organization, knowledge workers are creating preconditions for increasing competitive ability of the organization. Implementing modern management methods and techniques is directly 
based on application and improvement of knowledge productivity, both of individuals and of the whole organization

\section{PROCESS OF MANAGING MARKETING IN MODERN BUSINESS - MARKETING ATTRIBUTES WHICH DETERMINE THE COMPETITIVENESS OF ENTERPRISES}

The main goal of modern business is achieving business excellence on the global market. According to some views (Đorđević, et al., 2018), business excellence has as a result leader competitive position. Both terms oblige enterprises to constantly work on improving their knowledge and skills, to develop new products, encourage innovativeness among employees, follow the demands of final users, etc.

Modern business requires changing the way of thinking related to the organization of business functions within the enterprise. Starting from traditional views, characterized by linear way of thinking, where all business functions had the same significance, enterprises today should turn to more proactive thinking that includes understanding and creating changes. This also includes restructuring business functions within modern enterprises. Some time ago, all functions were considered equal and the advantage was being given to production for a long time. However, with the establishment of globalization and the development of new competitive relations, this model has been objectively overcome. Hamel (2009) believes that reengineering, reducing costs, constant development, outsourcing and offshoring are completely consistent with the genetic preferences of big companies. Ultimately, this means that it is important for a modern business organization to directly perform only those business functions that are directed towards the future, or the ones that have a strategic sign.

In modern business conditions of managing enterprises, especially distinguished business functions are the ones that carry a strategic sign because of their market orientation and those are:

- marketing,

- quality and

- research and development, (Đorđević, \& Ćoćkalo, 2010).

Every business organization is directed towards the market because there it realises its products and services, competes in the market game with the competitors, establishes a system of partner relations with the suppliers and satisfies the demands of consumers. Marketing is a business philosophy that deals with the market and the company's business. It means that marketing is of essential importance for market operations of an organization. Marketing has to spot possible market opportunities and transform them into a new product that will be accepted by the customers. Innovation starts and ends with marketing. By combining innovation with quality marketing achieves defining stable market position and long-term growth. Innovation represents a specific enterpreneurs' tool, means by which they use change as a possibility for performing different business activities. Innovation creates resource. It is a result of performance, marketing, research and development. Successful innovation must harmonize coordination of each technological innovation, as well as of the entire marketing function. Marketing is not necessary only as an additional effort for a technological innovation to become successful on the market, but it is important in the entire process of technological innovation. Quality represents the quality of the organization's business and it is projected at the executive management level. It is a management phenomenon and it is focused on satisfying customers' demands. Quality implies implemeting a certain quality management model into the organizational structure. Quality management should result in the improvement of business productivity and customer satisfaction.

According to Kotler and Armstrong (1996), marketing is a social and management process based on which individuals and groups spot their needs and desires through creating and exchanging products and comparing them to other products. Marketing is a skill which is used to create value for customers and to help them become wealthier. Every marketer's moto is: quality, service and value.

In the modern business, enterprises need a new way of thinking which includes leaving disfunctional management methods and techniques and applying modern ones. According to Grubor (2012), changes in marketing management are the consequence of the modern social factors' influence and they have noticeable implications on the entire marketing program. Achieving competitive advantage demands from marketing managers to think beyond presence, instead of 
S. Bešić and Creating the model for the implementation of marketing attributes

customers, as well as beyond organizational parameters.

One of the most important shifts in the marketing theory and practice during mid-nineties of the last century was defining marketing relations both in the conceptional and practical sense. According to Kotler, Keller and Martinović (2014), modern understanding of marketing represents hollistic marketing which is consisted of the following dimensions:

1. Internal marketing,

2. Marketing of business results,

3. Integrated marketing and

4. Relationship marketing.

Internal marketing represents relations between the marketing sector, management and other sectors in the company. Marketing of business results is directed towards increasing sales revenue, brand market value, towards ethics, community, business and environment in general. Integrated marketing assumes relations that are caused by communication, products, services and channels. Finally, relationship marketing represents relationships between partners, consumers and marketing channels.

Brookes and Little (1997) defined a new model of market performance marked as relationship marketing while they were studying market appearance of enterprises in new, global circumstances. This model is based on:

- Database Management,

- Interactive Marketing Communication and

- Network Marketing.

Marketing based on Database represents an organized set of data on individual customers, current or potential ones, including geographical, demografic, psycho-graphic data, as well as the data related to behaviour during the consumption process. Interactive marketing represents a set of interactive relations, mostly at the level of personal communication, aided by Information technology. Network marketing represents a set of connections and relations, mostly of strategic nature both at personal level and the relationship level among enterprises. It is most often about making strategic alliances and partnerships among the enterprises belonging to a particular branch.

Adequate marketing management is nowadays an assumption of achieving competitive advantage on the global market. Marketing creates growth of the modern business organization and marketing management, while connecting marketing with research, development and quality represents the basis of successful business. According to Kotler et al. (2014), successful marketing is not a coincidence, but the result of careful planning and organizing by using the most modern instruments and techniques. New marketing must deal with creating, communicating and delivering superior values to the target group of consumers. Therefore, marketing is the generator of the company's growth.

Global market, burdened by fast changes, creates a strong competitive activity. Kotler and Caslione (2009) speak about the phenomenon of hypercompetitiveness, that assumes such market conditions in which technologies and offer are totally new, the standards and rules are becoming fluid and they cause competitive progress that is impossible to be stopped. Hypercompetitiveness is characterized by fast competitive progress and therefore competitors have to build new advantages in a short period of time in order to be better than their rivals. In order to avoid the influence of market turbulences Kotler and Caslione (2009) suggests the application of a management system called Chaotic. Management System Chaotic helps managers to reconsider the whole approach to management and marketing during recession and similar turbulent periods. Moreover, managers have to find a way to develop the system for early warning and identification of the first signs of changes, especially disastrous innovations and shocks. Then, it is important to make detailed, the worst, best and most expected scenarios by using the strategies for facing each of them, to cut costs strategically or to increase productivity, to secure market share in the fundamental consumer segment, to comprise strategic planning in shorter, three-monthly cycles in order to monitor the company's pulse better and easier so as to prevent potential disastrous consequences of .

From the strategic point of view, companies have to stay focused on satisfying their target customers' needs, especially paying attention to their best customers. Companies cannot start to cut costs until they estimate what is happening with their customers, competitors, distributers and suppliers. A company must operate in a way that is the most promising when it comes to keeping clients, power of the brand and its long-term goals, 
as well as talented individuals within the organization itself.

Taking into consideration the new marketing horizon oriented by further technological development and permanent changes in the environment, marketing model born in the new millenium is consisted of three dimensions of marketing comprehension: subphenomenon, phenomenon and superphenomenon (Acharol, \& Kotler, 2012). Marketing seen as subphenomenon assumes customers' experiences and observation system. Marketing as a phenomenon means that we need rationalization and innovation outsourcing. In the future, the focus will be on micro production systems which will make products to satisfy demand near the very place of consumption. Finally, New business approach implies giving advantage to welfare of the society and customers in relation to welfare of marketing management. The key issues of global marketing will be the issues of sustainability and poverty reduction.

Market and marketing practice are showing day by day in which direction marketing should go. Social media made a revolution in the world of marketing, while digital marketing and technology transformed the way of doing business. For several years, the theory of technological development management is dealing with the industry 4.0. In the digital economy consumers are socially connected to one another by horizontal communication networks. Customers are more informed than ever and they can find almost all information about any product, service or company by surfing the Internet and contacting other people on social media. The Internet and social media created radically new media and sources of information, as well as new means for direct sales. Customers are more frequently ready to buy new brands and trust them if their price is lower than some globally known brands which are more expensive. Competitors are now able to copy each new product more quickly and in that way they can shorten the time of innovation investment return. Competitive advantage in modern economy nowadays lasts much shorter and those changes require radically new ways of thinking of managers and marketing experts.

New way of thinking about the role of marketing in business starts with the understanding of the essence of the product. It is necessary to define in a right way what the product brand represents and then to perform innovative activities related to the product and the brand itself, taking into consideration market demands. Marketing experts should accept the new market reality and create brands which act as humans, meaning that they should be available and attractive. These experts should shape brands in such a way that they become authentic and fair, that they accept their direction and stop trying to look perfect.

Kotler, Kartajaya, and Setiawan (2017) explain that Marketing 4.0 represents a marketing approach which combines direct and indirect interaction between companies and consumers. Kotler points out that we are not dismissing traditional marketing, but we are joining and combining traditional and digital. He believes that technological convergence ultimately leads to the convergence between digital and traditional marketing. The marketer's role is to lead the consumers through their journey from the awareness to the final step of the product advocacy. In the current hyper-connected marketing environment consumers are moving from the awareness (I know about the product), through action (I buy the product), until they reach the advocacy level (I recommend the product). Main orientations of marketing should be:

1. from exclusive to inclusive,

2. from vertical to horizontal and

3. from individual to social.

The market is becoming inclusive while the social media are reducing communication barriers between companies and consumers. Consumers are becoming more horizontally oriented and the buying process more vertically oriented than before. They are transfering their own advice and recommendations, as well as the ones coming from companies.

Marketing experts have to think about the horizontal connection between consumers, inclusion and business directed towards the society.

\section{RESEARCH ON THE OPINIONS OF MANAGERS IN DOMESTIC ENTERPRISES RELATED TO THE MARKETING ATTRIBUTES WHICH DETERMINE THE COMPETITIVENESS OF ENTERPRISES}

Research on the opinions of managers in domestic enterprises related to the marketing attributes which determine the competitiveness of enterprises was realized in order to determine possibilities for 
improving marketing practice in domestic enterprises. The research was carried out in the period between December 2017 and April 2018 on the territory of the Republic of Serbia with the purpose of collecting opinions from company managers about the possibilities for creating a new business model based on the application of modern marketing management methods and techniques, in order to improve business efficience and competitiveness. The research sample was designed to a size of 250 units (company managers), while the research results include 249 units. According to the answers of company managers to the survey questions, some main assumptions can be made which have a creative impact on the process of improving business quality of the business organization and of marketing management.

The goal of the research was to identify all the factors which determine the new model of marketing management in order to improve company's competitiveness. It should result in creating a new model for implementing modern marketing methods and techniques which have an impact on the process of improving company's competitiveness, taking into consideration specificities of domestic economy as a transitional one, together with the need of including domestic enterprises in the global economic flows. Model should be adjusted to the conditions in which domestic enterprises operate. When defining the research, the starting point was a general hypothesis that says it is possible to create a theoretical model for improving the competitiveness of domestic enterprises on the basis of applying modern marketing methods and techniques. This model would include demands and needs of modern business subjects in order to improve business efficiency and achieve competitive advantage on the global market, taking into consideration global business trends and transition economy characteristics. Also, other two separate hypotheses were defined:

- domestic enterprises are not applying modern marketing methods and techniques enough which results in poor competitive advantage in the international framework and

- domestic enterprises are not applying modern marketing methods and techniques enough which results in poor competitive ability in the international framework.
Out of 249 surveyed organizations, $126(50.6 \%)$ are in private property, $109(43.8 \%)$ in state property and the rest of 14 organizatons $(5.6 \%)$ is in mixed property. The number of employees in surveyed enterprises was: up to 10 employees in 26 organizations (10.4\%), from 10 to 50 in 41 of them $(16.5 \%)$, from 50 to 250 employees in 57 organizations $(22.9 \%)$ and over 250 employees in 125 organizations $(50.4 \%)$. The highest number (around one fifth) of surveyed organizations is doing business in the field of traffic and telecommunications, followed by the fields of trade, finance and industry, while crafts and agriculture are the least represented. The highest number of employees who answered the survey were managers of the organization (around one fifth), followed by directors, sector managers, owners and department managers, according to the frequency. The answers were given the least frequently by counselors and employees in other positions.

The most important factors for improving business of domestic enterprises are the following: improving business quality $(20.49 \%)$, training of employees $(20.22 \%), \quad$ increasing business productivity (13.11\%), improving technical and technological base of business (11.61\%), development and application of Information Technologies (11.48\%). As main obstacles in developing competitiveness of domestic enterprises, the following can be selected: lack of financial capital (27.34\%), lack of resources $(20.05 \%)$, lack of knowledge $(17.72 \%)$, outdated equipment and technology (17.31\%) and inadequate use of modern management methods and techniques $(6.87 \%)$. Analyzed managers defined some main characteristics which a modern organization should have and they are: efficiency $(20.08 \%)$, innovativeness $(19.39 \%)$, productivity $(14.37 \%)$, creativity $(11.99 \%)$ and flexibility $(9.9 \%)$.

As the most important marketing goals, analyzed managers point out the following: improving business quality (38\%), achieving value for customer $(22 \%)$, developing competitive ability $(18 \%)$, achieving business excellence $(13 \%)$ and appearing on the global market $(7 \%)$. Analyzed managers also point out the following marketing methods and techniques used in order to establish competitiveness: analyzing customer satisfaction (16.83\%), improving sales $(16.40 \%)$, public relations $(11.08 \%)$, direct marketing $(10.93 \%)$ and branding (10.07\%). 
In the past year analyzed managers were mostly trained in the field of developing products and services (19.83\%), quality (17.24\%), managing human resources $(15.52 \%)$, managing information systems (11.64\%), marketing (11.64\%), international business (8.62\%), managing technical systems $(7.76 \%)$ and business administration $(6.9 \%)$. When it comes to the process of training employees in domestic enterprises, the highest number of examinees, $19.24 \%$ of them pointed out that the most important field of training employees was managing information technologies (17.18\%), developing products and services (16.49\%), marketing (14.43\%), managing human resources (11.34\%), managing technical systems (7.9\%), business administration (7.56\%), international business $(5.15 \%)$.

\section{PRESENTATION OF THE MODEL FOR IMPLEMENTATION OF MARKETING ATTRIBUTES WHICH DETERMINE THE COMPETITIVENESS OF DOMESTIC ENTERPRISES}

On the basis of presented research results, assumptions for creating the management model were made. The model for improving business efficiency of domestic enterprises incorporates all the elements which define business excellence, taking into consideration characteristics of domestic enterprises and transitional economies.

Having in mind the accomplishments of the international theory and practice in achieving business excellence, as well as in establishing a standardized way of doing business and managing business processes, the model for improving business efficiency of domestic enterprises is consisted of important elements which are giving a theoretical framework and those are:

- process approach,

- market focusing,

- collecting and analyzing information,

- constant improvement.

Process approach means that the entire organization business is considered related to mega and regular processes. In order to achieve business excellence, models TQM and QMS switched to the process aproach which enables considering the wider picture of one's organization business. The system of quality management consideres the entire business life through processes and in fact, all processes can be classified into three groups: management processes, support processes and the processes related to the realization of basic enterprise activities.

The market makes basic demands related to the business organization. The organization gets all its resources from the market, it performs business on the competitive market and it realizes its products and services there. On the other hand, the market valorizes business efficiency - more successful organizations are selling more than others because they have better productivity and quality and they perceive customer needs and satisfy them better.

Collecting information from the market is essential in the process of decision making about business, including all the information created within the enterprise as well. Collection of all the information from the organization and beyond, those that already exist and the ones that are about to be created, represent the essence of good business decision making. Particularly important are the information related to the customer demands and the anaysis of their satisfaction.

Constant improvement is included in all concepts of quality management, starting from TQM to the quality management system nowadays, which represents the basis for building integrated management systems. Constant improvement in time is the core of successful business, improvement leaders are all employed in the organization, while the improvement goal is to achieve not only business excellence, but the quality of life.

Model for implementing marketing attributes which determine competitiveness of domestic enterprises includes the following elements:

- analyzing market demands,

- the most important factors for improving business of domestic enterprises,

- main obstacles in developing competitiveness of domestic enterprises,

- the most important characteristics of modern organizations,

- process of marketing management,

- marketing goals,

- implementing marketing management methods and techniques,

- directions for improving business,

- analyzing interest group satisfaction,

- constant business improving. 
This model starts from the strategic focus on costumers, as well as on relations and connections which derive from customer demands related to the organization and it ends with analyzing satisfaction of interest groups. The presented model should improve competitive advantage of domestic enterprises, especially from the point of view of marketing attributes and application of modern marketing methods and techniques in the business practice.

Regarding previously analyzed research results, main directions of business improvement in domestic enterprises are the following:

- adequate application of modern management methods and techniques,

- wider and more comprehensive application of quality and integrated management systems with the goal of improving business quality,

- business based on improving knowledge productivity,

- development of innovative performance in domestic enterprises.

When it comes to the presented model, following facts can be noticed:

- Analyzed managers of domestic business organizations were good in noticing main issues in domestic economy which have an impact on less successful business performance and competitive ability,

- There is awareness of the need to apply modern management methods and techniques which have an influence on the enterprise development, business efficiency and competitive ability,

- Analyzed managers recognize the need for constant development of themselves and their employees. That is extremely important because, in the time of crisis, the biggest asset of an organization are its employees while their knowledge and skills are the key resource for the future.

Model takes into consideration the following facts as well:

- respecting the economic reality of domestic economy,

- respecting the reality of transitional flows and negative effects of the economic crisis from 2008,

- accepting the facts that foreign partners of domestic companies from the EU are insisting on the application of international managment standards and on the standardization of business quality.

The business practice of enterprises coming from the most developed world countries points to the fact that the innovativeness and productivity are the key factors for improving modern organization's business. Business events on the global economic scene in the last decade are showing that newly industruialized countries also accepted the business model based on constant improvement of business productivity and on the development of quality, innovation, products and the organization itself. Productivity, quality and innovation are in the focus of considering all strategic variants for improving competitive ability of business organizations and competitiveness of nations.

Main directions for improvement related to the results of the presented model are:

- relationship marketing development,

- constant improvement of business quality and

- permanent knowledge improvement of domestic managers.

Relationship marketing is a marketing approach that does not encourage the competitiveness only through market battle, but it also emphasizes cooperation and interdependence between all market actors, as well between other interest groups in the enterprise's business environment. Relationship marketing recognizes the importance of all participants in the marketing process suppliers, employees, distributers, dealers and retail sellers, who all cooperate in order to create higher value for the customer target group. The majority of domestic enterprise managers pointed out that, in their organization, marketing is applied according to the needs - $29.78 \%$, partially $26.22 \%$, within the project $-24 \%$ and finally, as an integral concept $-19.11 \%$. Based on the presented results, it can be concluded that marketing in domestic enterprises is mainly not applied as an integral concept, but according to the needs (e.g. campaigns related to sales increase), partially and within a specific project (introducing new product), which is not appropriate considering the business demands of global economy. In majority of enterprises ( $73.49 \%$ of them), there is a special organizational unit for realizing marketing activities. The biggest number of enterprises $36.6 \%$ of them, realizes marketing through the marketing service, then through the marketing 
department $-28.96 \%$, marketing sector $-20.77 \%$ and through the marketing directorate $-5.46 \%$. According to the mentioned results, it can be noticed that in the process of organizing marketing activities in domestic enterprises dominate lower organization forms - marketing service and department. In the majority of enterprises, $87.95 \%$ of them, marketing activiites are being planned. The most common way of marketing planning is according to the project $(39.27 \%)$, followed by short-term planning up to one year $(31.96 \%)$ and mid-term planning (16.89\%). As it can be seen, the most dominant are the enterprises which approach planning through projects and during one year time, which is not appropriate according to the needs of managing modern business organizations in the global business. Only $16.89 \%$ of enterprises are carrying out mid-term planning of marketing activities. When it comes to the application of certain marketing techniques, the most represented marketing activities in domestic enterprises are the following: customer satisfaction analysis $(16.83 \%)$, improving sales $(16.40 \%)$, public relations $(11.08 \%)$, direct marketing $(10.93 \%)$, branding $(10.07 \%)$. The hierarchy of mentioned activites and marketing techniques in domestic enterprises is logical considering the fact that domestic enterprises are constantly directed towards increasing sales on the limited domestic and regional market (Western Balkan, part of the EU market) without more significant seems for increasing placement in the international framework and with the need for maintaining business quality in conditions of chronic lack of financial capital. It can be concluded that certain modern marketing techniques, like customer relationship management - CRM (7.91\%), marketing initiative in the wider complex of corporate social responsibility $(7.91 \%)$, integrated marketing communication (7.62\%), network marketing $(2.15 \%)$ or lateral marketing $(1.43 \%)$ are used significantly less in domestic enterprises. The reason for this is surely the lack of money, but also a lack of knowledge, as those are mainly marketing methods and techniques based on knowledge.

Constant impovement of business quality is the imperative of modern economy. It is realized by long-term building of the quality management concept and by applying international management standards. Domestic economy is the leader in the region when it comes to the number of certified organizations regarding ISO management standards which is logical because of its size compared to the other western Balkan countries, but it is still not enough compared to the total number of active enterprises in Serbia, as well as to other eastern European countries, like Greece, Romania, Bulgaria, Hungary, etc. Domestic managers are aware of the necessity to improve business quality by applying integrated management systems. According to the opinions of analyzed domestic enterprise managers, constant improvement of business quality is the most important business and marketing goal (38\% of all answers). Constant improvement of business quality is the most represented marketing activity goal in largest organizations ( $45.11 \%$ of all goals) where the number of employees is over 250. Quality management is placed as one of the key factors of modern organization competitiveness and all domestic managers are aware of this fact, especially the ones from enterprises that are internationally oriented.

Constant improvement of knowledge productivity, as the fundamental assumption of improving business productivity of the modern organization, has become a central issue of all global corporations. The research results pointed out the need for improving knowledge of managers, as well as employees in domestic organizations. If organization managers' opinions based on traditional organization resources are considered all together, it can be concluded that almost $54 \%$ of examinees consider that their organizations are not based on knowledge or creating it. This is logical considering the fact that domestic economy, compared to the World Economic Forum classification, belongs to the group of countries led by efficiency, which is the case with almost all transitional economies and one part of newly industrialized countries. The lack of financial capital and general lack of business resources prevents domestic enterprises from dedicating themselves to knowledge and from basing their internal economy on the constant knowledge improvement.

Main directions in marketing improvement in domestic enterprises are the following:

- application of the integral marketing concept,

- more adequate formation of the organizational marketing unit in domestic enterprises,

- methodical approach to marketing planning with the purpose of successful marketing function management, 
S. Bešić and Creating the model for the implementation of marketing attributes

- more adequate and faster application of modern marketing methods and techniques.

The application of modern marketing techniques is the essential precondition for a successful business of domestic enterprises. Misunderstanding of marketing is typical for transitional economies. Domestic business organizations have to use foreign business experiences in the process of business internationalization, which means that they have to actively apply the integrated marketing concept and modern marketing techniques, taking into consideration the need to apply also other modern management methods and techniques, like integrated management systems, benchmarking, reengineering, etc. Most of modern methods and techniques are based on knowledge.

According to Đorđević, Ćoćkalo and Bogetić (2016) domestic managers have to become efficient and then to make other employees efficient, too. Generally speaking, newly made framework of human society asks for people who are representatives of successful synthesis of knowledge, skills and attitude. This threedimensional approach is conditioned by modern business performance. An individual must satisfy a wide spectrum of features in order to successfully respond to tasks imposed by modern organization. These requirements are becoming increasingly important in the activities related to marketing.

\section{CONCLUSION}

Implementing global experiences and internationally accepted business practice, as well as modern management methods and techniques, is the basis of improving business efficiency of domestic enterprises and developing competitive ability on the global market. The special emphasis here is on the wider acceptance of the relationship marketing concept, quality management systems and integrated management systems, which represent a basis for strenghtening competitive ability of domestic business organizations in the international framework.

Main directions of marketing improvement in domestic enterprises are the following: application of the integrated marketing concept, more adequate creation of the organizational marketing unit in domestic enterprises, methodical approach to marketing planning with the purpose of successful marketing function management, more adequate and faster application of modern marketing methods and techniques.

The presented model for improving business efficiency of domestic enterprises points out the necessity for the application of the modern marketing concept - relationship marketing. Relationship marketing represents a new model of thinking based on information, innovation interaction and connection. Implementation and development of integrated management systems represents a basis for achieving business excellence and organization competitiveness goals. The presented model can be implemented considering the following facts: respecting the domestic economic reality, respecting the reality of transitional flows and negative effects of the economic crisis from 2008, accepting the fact that the foreign partners of domestic enterprises from the EU are insisting on the application of international management standards and on the standardization of business quality.

\section{REFERENCES}

Achrol, R. S., \& Kotler, P. (2012). Frontiers of the marketing paradigm in the third millennium. Journal of the Academy of Marketing Science, 40(1), 35-52. doi: 10.1007/s11747-011-0255-4

Brookes, R., \& Little, V. (1997). The new marketing What does' customer focus' now mean? Marketing and Research Today, 25(2), 96-105.

Bešić, C., Đorđević, D., \& Bešić, S. (2017). Global market and new competition relations. The Review of International Affairs, LXVIII(1166-67), 49-64.

Bešić, C., \& Đorđević, D. (2017). Savremeni menadžment trendovi [in Serbian]. Čačak: FTN.

Đorđević, D., \& Ćoćkalo, D. (2010). Fundamentals of marketing. Zrenjanin: Technical faculty "Mihajlo Pupin".

Đorđević, D., Ćoćkalo, D., \& Bogetić, S. (2016). The analysis of marketing concept implementation in domestic enterprises. Journal of Engineering Management and Competitiveness (JEMC), 6(2), 120-128.

Đorđević, D., Ćoćkalo, D., \& Bogetić, S. (2018). The role of quality in thee process of improving competitiveness of domestic economy. International Journal of "Advanced Quality", 46(1), 21-26. doi: 10.25137/IJAQ.n1.v46.y2018.p21-26

Drucker, P. (2003). My view on management. Novi Sad: Asee Books.

Grubor, A. (2012). Marketing management in the function of development of a new private sector. Business Economics, 6(1), 79-90.

Hamel, G. (2009). The future of management. Novi Sad: Asee Books. 
Kotler, P., \& Armstrong, G. (1996). Principles of Marketing. New Jersey: Prentice-Hall International Inc.

Kotler, P., \& Caslione, J. A. (2009). Chaotics: The business of managing and marketing in the age of turbulence. Zagreb: Mate.

Kotler, P., Kartajaya, H., \& Setiawan, I. (2017). Marketing 4.0: Moving from traditional to digital. Hoboken, New Jersey: John Wiley and Sons Inc.
Kotler, P., Keller, K. L., \& Martinović, M. (2014). Marketing management. Zagreb: Mate.

Martinović, M. (2009, 14.11.2017). The worst reaction to the sudden turbulence and recession is a broad cost-cutting [in Croatian]. Lider.

Porter, M. E. (2007). Competitive advantage. Novi Sad: Asee Books.

Thompson, A. A., Strickland, A. J., \& Gamble, J. E. (2008). Strategic management. Zagreb: Mate.

\title{
KREIRANJE MODELA ZA IMPLEMENTACIJU ATRIBUTA MARKETINGA KOJI DETERMINIŠU KONKURENTNOST DOMAĆIH PREDUZEĆA
}

\begin{abstract}
Globalno tržište i uspostavljanje novih konkurentskih odnosa zahteva novi pristup u upravljanju poslovnom organizacijom, kako u koncepcijskom, tako i u organizacionom smislu. Savremene organizacije koje aktivno i kontinualno primenjuju savremene metode i tehnike uporavljanja, imaju znatno bolju šansu da ojačaju svoju konkurentsku sposobnost na globalnom tržišu i da zauzmu stabilnu tržišnu poziciju sa perspektivom za dalji tržišni rast. $U$ tom smislu, potrebno je da domaća preduzeća implementiraju one upravljačke tehnike koje potenciraju dugoročno opredeljenje ka konkurentnosti. Ovde se prevashodno misli na marketing odnosa, standardizaciju kvaliteta poslovanja, kao i druge upravljačke tehnike koje se zasnivaju na znanju. Primena savremenih tehnika marketinga je suštinski preduslov za uspešno poslovanje domaćih preduzeća. Pogrešno razumevanje marketinga je tipično za tranzicione ekonomije. Domaće poslovne organizacije moraju da koriste inostrana poslovna iskustva u procesu interancionalizacije poslovanja, a to znači da aktivno moraju da primenjuju integralni marketing koncept. U ovom radu se daje prika rezultata istraživanja stavova rukovodilaca domaćih preduzeća u odnosu na potrebu za unapređenjem marketing prakse. Takođe, dat je prikaz modela za primenu atributa marketinga koji determinišu konkuretnost domaćih preduzeća.
\end{abstract}

Ključne reči: Marketing, Konkurentnost, Globalno tržište, Upravljanje, Znanje, Model. 